\title{
Potentials of Constituency Development Catalyst Fund Act of 2009 in Enabling Implementation of CDCF Projects in Vwawa Constituency, Tanzania
}

\author{
Frowin L. Mgani Carolyne I. Nombo Emanuel E. Chingonikaya \\ Department of Development Studies, College of Social Sciences and Humanities, Sokoine University of \\ Agriculture, P. O. Box, 3024, Morogoro, Tanzania
}

\begin{abstract}
Constituency Development Catalyst Fund (CDCF) Act is a legal instrument that provides directives in the planning and administering of the funds used to support development projects. This paper analyzed the potentials of CDCF Act of 2009 in enabling the implementation of CDCF progaramme in Vwawa Constituency, Tanzania. Data collection was through semi-structured interview, focused group discussion (FGD) observation and documentary review which were later transcribed and subsequently analyzed. The findings indicate that, the projects funded were proposed by the villagers, mainly from the existing projects that were already in process of implementation. It was also was found that, legal measures were taken against those who misappropriated and or assisted to misappropriate the CDCF. Based on these findings, the study concludes that, the process of initiation of the projects was not practical in a real sense since community members did not initiate new projects as per CDCF Act. As such, the paper recommends review of some of the CDCF Act, 2009 articles to include issues pertaining initiation of projects to be disbursed by CDCF that the CDCF Act should emphasize on selecting projects from among the existing projects rather than initiating new projects, because this is what is practical in the study area.
\end{abstract}

Keywords: CDCF Act, CDCF Implementation, CDCF administration, Misuse of CDCF.

DOI: $10.7176 / \mathrm{PPAR} / 10-10-02$

Publication date:October $31^{\text {st }} 2020$

\subsection{Introduction}

Constituency Development Funds (CDFs) are forms of fiscal decentralized government funding mechanisms in which money from the central government is channeled to each constituency for development projects intended to address development projects and increases community participation in development projects at the grassroots level (Ngigi, 2015; Chibomba, 2013; Malya and Kessy, 2013). CDF policy has been practiced in different African, Asian and Caribbean Countries, and when it was introduced in Tanzania in 2009, it was renamed 'Constituency Development Catalyst Fund (CDCF)'. CDCF, the Tanzanian version of CDF is an improved version from Kenya, Zambia and some other countries (CPA, 2016; Opiyo et al, 2016; Otien, et al, 2015 and Chibomba, 2013). It was envisioned as a catalyst for accelerating self-help development efforts at grassroots level (Chesang et al; 2016).

The introduction of CDCF in Tanzania was not an overnight process, but a long process, which can be traced back to the 1990s when discussion about the introduction of CDF began. Although the discussion for establishing CDF has been a parliamentary discussion core issue from the mid-1990s (URT, 2009 as cited by Tsubura, 2014), it was in 2006 that the Tanzanian Parliament established a committee to review the standing orders, and a set of written rules (URT, 2006 as cited by Tsubura, 2014) to allow its establishment. The committee travelled to several countries such, Kenya, Zambia, Mauritius and India for CDF implementation fact finding and learning and later submitted of their study to the Parliament. Once report was submitted, what followed was the drafting of the CDCF bill and subsequently submitted to parliament in June 2009. The Bill was discussed and passed in the Parliament. Thereafter, was assented into law.

CDCF Act No. 16 of 2009 (hereafter referred to as CDCF Act, 2009) is a legal instrument set for guiding the implementation of the CDCF funded projects. Several studies carried out in different countries about CDF (named different in some countries) stipulate that in some constituencies where the fund was sent, there was effective implementation of the CDF Act in managing the fund (Chesing, et al 2016; Opiyo, et al 2016; Otien, et al, 2015; Mutie, 2014; Auya and Oino, 2013; Oyugi and Nyaguthi, 2013;). Some literatures from Kenya differ in their findings with regard to CDF. For example, while Francis et al (2009) viewed that CDF in some constituencies have performed poorly in managing CDF fund and its projects. Florence, (2012) pointed out that; some projects implementing committee were ignorant about CDF objectives and principles perceiving the funding mechanism as another source of free money for personal gain. This situation jeopardizes aims and goals of the CDF despite of the presence of its legal foundation. In Vwawa such incidence is not clearly known as there is still insufficient information about the implementation of CDCF Act and therefore it is salient to scientifically produce useful data that can help in understanding the potentials of CDCF Act, 2009 in implementing CDCF activities. It is for this and similar reasons that, this study was conducted, with the intention of analyzing the potentials of Constituency Development Catalyst Fund Act of 2009 in enabling the implementation of CDCF projects in Vwawa constituency. 
It specifically examined the process of initiations of CDCF supported projects and determined the administration of $\mathrm{CDCF}$ and various conditions in Case of misappropriate use of CDCF.

\subsection{Legal Framework}

The CDCF Act No. 16 of 2009 was enacted to guide the transfer of funding from the central government to electorate constituencies for the development projects at the grassroots. It aimed at providing an orderly allocation and disbursement of funds to constituencies and for prudent management, compilation or records, returns and reports from constituencies, and on other related matters. It was established to be applicable to both Mainland Tanzania and Tanzania Zanzibar and became operational on $1^{\text {st }} \mathrm{July,} \mathrm{2009}$. It is applied in relation to a portion of the national annual budget devoted to the electoral constituencies for purposes of development of each of such constituencies (URT, 2009). The CDCF Act, 2009 provided different directives in implementation of the funds. It gives the room for ordinary citizens to participate in the initiation of the projects. This is in accordance to article 12 (1) of CDCF Act, 2009 provides that, the projects to be funded by CDCF shall be initiated by the members of the community who are residents in a constituency. In this case, CDCF implementation have to facilitate the process by mobilizing community members to participate in initiation of projects, planning implementation, monitoring and evaluation and practically abiding with them (CPA, 2016).

The CDCF in its fiscal form have to be managed and administered in an efficient, effective and transparence manner. The CDCF Act, 2009 indicated how the fund should be administered and kept before it is used to support development projects. This is indicated in Article 5(3); 21(2) and article 22(1) of the CDCF Act, 2009. Legal measures taken in case of the misuse of the funds are essential in the implementation of CDCF Act, 2009. The measures indicated in article 28 (2) of the CDCF Act, 2009 are fine not exceeding fifteen million Tanzania shillings or imprisonment of five years or both. This is to enhance and show greater accountability in the society (URT, 2009).

\subsection{Decentralization Theory}

The study was guided by Decentralization Theory as propounded by Alexis Tocquesville in 1820s. The theory considers "transfer of responsibilities, resources, or authority from higher to lower level of government as the best practice and imperative in discharge of public affairs" (Fallet, 2005). Elaborating it further Barnet (1999), argue that decentralization is the transfer of authority, responsibility, and accountability from central to local government For Kisumbe et al (2014) decentralization is a vehicle of reforming governance with the focus to transfer some political, financial, and administrative power from central government to local government and can also be driven by desire to move services closer to the people. Nevertheless, for the World Bank (2004) decentralization encourages the desire to bring politicians and policy makers closer to clients and to make services more effective, although success depends on how decentralization affects relationships of accountability and enhances fairness. Thus, taken as a political strategy (Kisambe et al, 2014). Decentralization is expected to boost public sector efficiency, as well as transparency, participation and accountability in service delivery and policy making (Mello, 2000). The assumption is that decentralization works by enhancing citizens' voice and in a way that leads to improved social services delivery. The mode of citizens' participation can largely be categorized into vote and voice (Kauzya, 2007). In Tanzania, decentralization is part of the efforts made by the government to improve social services delivery at local level (Molel, 2010). Decentralization was adopted with the aim of bringing government closer to the citizens because, in a system in which decisions about resources allocation and services delivery are supposed to be more responsive to local needs, usually people's directly involved in decision making or indirectly influencing those decisions is paramount (Massoi and Norman, 2009). In the context of this paper, Decentralization Theory was used to establish how responsibility, resources and authority from the central government were transferred to constituencies and ultimately to the citizens. In this context the lower level of the government that includes; CDC committee, WEOs, WDC, VEOs and ordinary citizens.

\subsection{Study Methodology}

The study was conducted in Vwawa Constituency in Mbozi District, Songwe Region. Vwawa Constituency is one among 265 electoral constituencies in Tanzania and is composed of 18 wards. The major economic activities in Vwawa are farming and livestock keeping. Vwawa was purposely selected because it is one of the 26 new electoral constituencies since 2015, the reason of selecting the new ones is to examine how the CDCF was managed in these newly constituencies. Simple random sampling was used to obtain Vwawa constituency out of 26 newly constituencies.

The study utilized qualitative research approach within which case study research design was chosen as most appropriate to guide the study. The study's targeted population constituted Village Chairpersons (VC) and Hamlet Chairpersons (HC), Extension Officers (EOs), Village Development Committee (VDC) members and ordinary citizens. Data collection was by means of Key informant Interview focused group discussion (FGD), interviews and observation. Observation focused on observing practical projects and CDCF disbursement provided in form 
of materials.

Data were collected from purposively selected 17 key informants from District Councils, wards and villages. The key informants included district planning officer (DPLO), ward executive officers (WEOs) and village executive officers (VEOs) who provided information on CDCF implementation in their administrative areas. To allow flexibility without affecting focus, semi-structured interviews were used with key informants. For Creswell (2012), interviews provide useful information when you cannot directly observe participants and they permit participation to describe detailed personal information. Data were also generated from focus Group Discussions (FGDs) involving ten groups comprised of 5 to 9 participants. The FGDs were conducted in village councils found in ten villages namely Mbewe, Ndolezi, Sakamwela, Hanseketwa, Senjele, Namlonga, Chimbuya, Isandula, Lumbila and Wellu II. In each selected village, a focused group discussion (FGD) was carried in small groups consisting of men and women. There were categories of FGD, the first category composed of ordinary citizens and the other consisted of village development committee members (VDC). The participants were purposively selected during an extra - ordinary villagers meeting called by the VEOs. The FGDs were guided by a well structured themes and topics for discussion.

Data were thematically analyzed and conclusions were drawn based on various themes identified from them. As Creswell (2012) puts it, the use of themes is another way of analyzing data because themes are similar codes aggregated together to form a major idea in the data base. The data recorded using a tape recorder were first transcribed. After transcription, different categories were created and labeled (open code process). The categories with the same codes were connected in a logical and meaningful way. Then the single core category was identified. Thereafter, the case studies sets in form of quantitative interpretations and descriptions were documented. This approach is collectively termed as content analysis.

\subsection{Findings and Discussion}

This paper focused on the aspect of CDCF Act, 2009 implementation and development project at the grassroots in Vwawa Constituency. The aspects dealt are as follows; CDCF projects initiations, procurement in CDCF funded projects, administration of $\mathrm{CDCF}$ and miscellaneous provision on $\mathrm{CDCF}$.

\subsection{Projects initiation and procurement process \\ 3.1.1 CDCF projects initiation}

In this aspect, the study focused on citizens who were involved in proposing development projects to be supported by CDCF and what followed after the selection of projects until the fund was provided for the projects. The findings showed that, villagers enlisted exiting projects in their villages. These were contrary to what the CDCF Act, 2009 demand, for which article 12 (1) indicates that, projects to be funded by CDCF are initiated by the members of the community who are residents of the constituency. As per findings, the criteria were for the projects that were in process of construction like building physical infrastructure and those which had reached the level of finishing. Projects proposed were sent to the Ward Development Committee (WDC) for approval thereafter it is then forwarded to the Constituency Development Catalyst committee (CDC) for consideration. This was narrated by one of the key informant from Mlangali ward:-

"When CDCF money is deposited in the district development bank account, WDC gives the chance to the villagers to propose the project to be supported and the village forward the proposal to WDC, then the WDC chooses the qualified projects based on the criteria given by CDC Committee and forward it to the CDC committee" (Key Informant 8: April, 2017).

Furthermore, the Vwawa constituency's CDC committee report (2016) revealed that a big number of projects to be supported by CDCF were proposed by community members from different villages, but only a few were selected. This was documented in CDC committee meeting minutes as follows;

... in financial year (FY) 2013/2014, 43 projects from 18 wards of the constituency were brought on the table for discussion and consideration. After assessing them the committee selected 31 projects based on the preferences order and based on those considered to have the likelihood of reaching the accomplishment stage/level (CDC Committee Meeting report, 2016:3).

The findings imply that, although the decisions about the projects to be funded were influenced by CDC committee, the constituents were not left behind on the issue of deciding which project to be supported. They were included as per requirement of Article 12 (1) of CDCF Act, 2009. The steps of selecting CDCF projects were followed as per CDCF Act, 2009. Starting with the first step at the village level, followed by WDC and lastly by CDC committee as top decision-making organ of the fund in the constituency as required by Article 12 (1) and 13 (1) of the CDCF Act, 2009. However, villagers did not initiate new projects to be supported by CDCF as per CDCF Act, 2009. What they did was selecting them from the existing projects which were in progress. Decentralization theory emphasize among other things, the transfer of authority from the central government to the local community members. Contrary to this, the findings show that community members in Vwawa constituency were not given fully authority to decide and initiate own new projects as per the CDCF Act and as per the theory requirements. 
This implies that the constituents were not yet fully empowered in making use of the CDCF fund something that may affect implemented project's sustainability.

According to Baskin (2010), projects selection begins at the grassroots level with villagers identifying potential projects, prioritizing them and presenting the final recommendation to the CDC committee. Article 11 (1) of the CDCF Act, 2009 indicates that, the CDC Committee deliberates on project proposals from all the wards in the constituencies and any other project which the CDC committee considers beneficial to the constituency. It is vital for the government bodies and agencies offering people with increased opportunities to participate in policymaking and provide their government with benefits of the collective expertise and information (Shrivastara, 2015). The selection of the projects to be disbursed by CDCF based on a preference that is focused on the projects that needed more and quick support. Apart from preferences bases, some projects were not selected because of lacking the criteria of reaching at the accomplishment stage/level. If it was a building for instance, at least it should be at the level of roofing. However, the amount of funds provided determines the quantity of projects to be selected for CDCF support.

Community members were grateful on the CDCF contribution to community development. The findings revealed that the $\mathrm{CDCF}$ contribution reduced the amount funds fund that was contributed by the villagers to development projects as per cost sharing principle. This was clearly narrated in one of the FGD in Namlonga village that;

CDCF is beneficial to the community; it reduces the amount of funds that is to be contributed by community members for development projects and motivates community members to work hard for the projects (FGD: May, 2017).

This means cost sharing in development projects is good for community members as it encourages selfreliance in the community. Community members are not supposed to wait for the government to provide each and every service. They have to work hand in hand with the government for their betterment. Citizens' participation is the key determinant factor for the success of devolution and good governance at the constituency level. Citizens participation is a two-way process where the government provides opportunities based on the interests of the governed among other things (Kadurenge, 2016). Citizens' involvement in the development activities is vital for their welfare. It facilitates efficiency and effective implementation of all the development projects in the villages.

The findings further show that, although villagers select projects to be supported by CDCF, but once the proposal of projects selected reaches at the level of CDC committee the top CDCF decision making organ, the committee decides which projects to be funded. The CDC committee has a power and authority to choose the projects even if it is not the choice of the citizens. This was confirmed by one of the key informant at the district level who said:

"The CDC committee has the authority to choose and implement the projects, even if the projects have not been proposed by citizens, if the project is more important and needs a support; the committee chooses that project" (Key Informant 16: June , 2017).

The implication here is that, CDC committee members are well informed about the fund compared to the awareness of the citizens about the fund. This is contrary to Decentralization Theory which emphasize on transfer of responsibility, resources and authority from the central government to the constituency and eventually to the ordinary citizens. This is because, the findings shows that there were no total transfer of responsibilities particularly to the project beneficiaries (constituents), since they were involved in proposing projects for which the CDCF funds are to be disbursed and not fully engaged in a final choice of the projects to be implemented as such activities were performed by the CDC committee.

Their intercessions to some choices made by constituents were influenced by being well informed about the fund and the preferred projects as per criteria needed. Citizen's choices and decisions are important, since their fully engagement add more value especially when they are fully involved in decision making concerning their welfare. Yet CDC committee may also consider the most important projects which might not be assessed clearly by the community members. It is evident that the MPs and the members of the CDC committee tend to dominate projects prioritization, selection, decisions and edge out public participation process (Tshangan, 2010). However, citizens' involvement ensures that common goods are in line with voters' preferences and public sector accountability (Shah, 2005). Poor participatory practices create mistrust, waste people's time and money and can seriously undermine future attempts at public engagement (Gaventa, 2002). Phiri (2016) in his study conducted in Zambia found that, there was limited involvement of local ordinary citizens communities in CDF projects monitoring despite the presence of the guidelines.

\subsubsection{Public Procurement in CDCF supported projects}

The CDCF Act, 2009 and Public Procurement Act No. 7 of 2011 (hereafter PP Act, 2011) emphasize on insuring observing and adhering to the public procurement standards. It reports on the manner that suppliers or tenderers are obtained at villages, wards and constituency levels. Procurement is one of the projects implementation process in a community in which different suppliers, tenderers and contractors are involved. The suppliers, contractors and tenderers must meet the criteria set by the procurement Act in order to part to the process. 
The findings indicated that, public procurements procedures were done in accordance to the public procurement Act, 2011 and article 15 (1-2) CDCF Act, 2009. It was found that contractors and suppliers were obtained in a particular village and in some few cases they were taken from outside the village. Nevertheless, CDCF Act, 2009 does not specify where the contractors / suppliers should be obtained from. This was explicitly made clear in one of the FGDs in Chimbuya Village. It was learned that;

...the procurement is done according to the law. However, normally the contractors and suppliers are obtained within a particular village. If there are no qualified contractors or suppliers they can be taken from outside the village or if the projects need engineers then the contractors are brought from outside (FGD. April 2017).

It was also observed that, in some villages, CDCF provided materials which were ready for use like desks for schools. In such circumstances, the CDC committee provided the tender to the carpenters to make several desks as requested by some schools, and thereafter they were distributed to schools that are in need. This was revealed in a CDC committee report that;

"The CDC committee meeting decided on providing a tender of making desks to a carpenters" group called AMANI LUMBILA because the group makes desks of good quality and at a lower price (that is 43,000 Tsh) per desk compared to other carpenters who charges higher prices ( that is 55,000 Tsh) per desk." (CDC committee report, 2015: 4).

The quotations above show the importance of local contractors and suppliers in holding the tender in CDCF supported projects since they can easily be monitored in terms of abiding to issues pertaining to financial transparency and accountability. The Government Notes No. 98 of 2005 article 15 (3) states that, "in applying exclusive preferences to local persons or firm, the procuring entity shall have the responsibility of ensuring that selected persons or firms are capable of providing quality services." Due to these facts, the local contractors can feel that they are considered and their presence as contractors in the community is recognized. Procurement management in the public sector is a tool for achieving political, economic, and social goals (Nkinga, 2003). CDCF committee and village officers following procurement process in obtaining contractors or suppliers increases demand for accountability and transparency in government. As such, the CDCF Act, 2009 provides governance mechanism to ensure that CDCF resources are used as intended and achieve their targeted objective. These include procurement procedures (rule of law), expenditure reporting (accountability), and bottom up planning (participation) (REPOA, 2014).

\subsection{Administration of CDCF and miscellaneous provision 3.2.1 Finance and administration of CDCF}

The paper here considers the administration of the funds from national level to the grassroots level. Its concerns are on how the CDCF funds are administered: who allocates the fund and how the fund is allocated at the level of the constituencies, wards and villages. From the documentary review the study found that, the 2009 CDCF Act applies to Mainland Tanzania as well as to Tanzania Zanzibar. In accordance with Article 5(1) of this Act, the governments allocate the fund for each financial year to each constituency. As per Article 4(2) of the same Act the CDCF is administered and managed by the minister responsible for local governments for the constituencies situated in mainland Tanzania, and minister responsible for the union matters in Zanzibar.

Often, the constituency is represented by an MP representing the constituents in the Parliament. For Tsubra (2014), MPs are directly involved in utilization of CDCF resources. It is clear that the successful execution of any CDF is contingent upon strong MP involvement and leadership (CPA, 2016). At the constituencies' levels, CDCF is managed by CDC committee that has the maximum of seven members. As per Article 10(1) of CDCF Act, 2009, the members of CDC committee are as follows: MP (Chairperson), DPLO (Secretary) two councilors, two WEOs in Tanzania mainland and in case of Zanzibar one Sheha, and one person nominated by the committee from among the active NGOs in the area, if any. CDC committee is one of the administrative organs that administer the funds. The role of the CDC committee is to scrutinize the proposed projects and finally decided the one to be funded. The CDC committee is the top decision making organ of the CDCF in the constituency. This was practical in the study area as documented in the CDC Committee report that,

"CDC committee members discussed and approved some development projects that were to be implemented in villages. Villages were provided with either cash or materials like cement, desks, windows, doors and iron sheets for the selected development projects. " (CDC committee report, 2015: 2).

The quote here means that, the committee was fulfilling its role as per CDCF, Act, 2009 and as an administrative organ. It was necessary for the CDC committee to decide on the projects to be funded because as a top decision making organ of the CDCF in the constituency knew the amount of fund provided for the whole constituency. It was the committee that had to budget basing on the amount of CDCF provided. It happened sometimes that the CDC committee had to prioritize the projects to the least developed wards, but some of them still fail to be implemented because of the cost-sharing requirement (REPOA, 2014). 
It was further found that, the fund sent to each constituency had to be deposited in the constituency bank account. Bank account is the safer place to keep funds and as such the constituency is obliged to keep its fund in that respective bank account opened before spending them to the development projects. As per Article 22 (2) of CDCF Act, 2009, "the bank accounts opened pursuant to sub-section (1) shall be separated from that of the council." However, the findings in the study area showed that, CDCF funds were deposited in a District Development Bank Account (DDBA) and not constituency bank account as demanded by the CDCF Act, 2009. A testimony by one of the officers at the district level is reproduced here as follows:

"The central government deposit CDCF into district council development bank account for all constituencies found in the district. Thereafter, the fund is provided to the constituency based on the amount each constituency was given from the central government. The planning officer received the list of the projects, thereafter deposit money in village bank account ready for the use in the projects."

(Key Informant 17: June 2017).

This may mean that there was no constituency bank account specifically for $\mathrm{CDCF}$ in the constituency. This is because the fund was deposited directly to the DDBA from the central government and thereafter deposited to the villages' bank accounts. This aspect may also mean that, the district avoided having multiple bank accounts in a district council for each constituency, due to the fact that, currently Mbozi district the district council where Vwawa electoral constituency is located have six bank accounts. The study findings are contrary to CDCF Act, 2009 which requires constituencies to open and operate a bank account specifically tailored for CDCF. Nevertheless, some study participants were of the opinion that it is not necessary to have special bank account for CDCF as long as the fund is safe and managed in accordance to the CDCF Act, 2009 once it is deposited in DDBA.

Furthermore, the bank account signatories were categorized into two categories, category A made of council director and council planning officer and category B is made of the council treasurer and the council accountant. This was according to Article 22 (3 a-b) of CDCF Act, 2009. Moreover, among four signatories of CDCF fund, only one signatory is a member of CDC committee as per CDCF Act, 2009, while the rest are officers from a particular district council where the constituency is found. Based on this, it was evident therefore that, there was no need of having special bank account for CDCF in each constituency found in the district. This is why Vwawa constituency did not have an independent bank account specifically for CDCF. If the law makers aimed letting each constituency to have a bank account; signatories would at least be among CDC committee members and not all to be obtained from district council officers.

\subsubsection{Legal measures taken in case of misuse of CDCF}

Like many other Acts, CDCF Act 2009, has various provisions aiming at safeguarding the fund in cases of misuse. In this part the paper focuses on the proposed legal measures to be taken if any responsible person goes against the requirements of the fund. According to Article 28 (1) of CDCF Act 2009, "any person who misappropriates assists or causes any person to misappropriate or apply the funds, or assets from the CDCF otherwise than in the manner provided in the Act, commits an offence." In section 2 of the article further emphasizes that, "a person who is convicted for an offense under subsection (1) shall be liable to a fine not exceeding fifty millions Tanzanian shillings or to imprisonment for a term not exceeding five years or to both." However, the findings from the study revealed that, in case of misuse of funds the convicted one were given lesser punishment than what is stipulated in the Act. This was made clear by one of the Key informants of Ihanda ward who observed that;

"In case of fraud, investigation is made to identify the criminals, once they identified and confess that they have stolen money or material, they are told to payback and the case ends there." (Key Informant 2: April, 2017).

In a FGD some villagers in Isandula village, a similar and more emphatic position was narrated as follows: ...the village has never experienced misuse of $C D C F$, but it has happened to other funds. However, if it happens, the village council takes legal measures; usually the offenders are to return the funds or materials with compensations (FGD. April 2017).

Community members are not behind in dealing with fraud and misuse of the public funds in the constituency although, the steps taken to a person convicted are challenging the CDCF Act, 2009, the punishment provided is minor compared with that indicated in CDCF Act, 2009. Article 28 (1) of the CDCF Act, 2009, is dealing with conditions or measures taken to the misuse of the $\mathrm{CDCF}$ and a person convicted for an offence is subjected to a fine. The findings reveal that in case of misappropriate use of funds investigations are made, for those convicted by village investigators for offences have to pay back the stolen money or materials. The findings here reveal something contrary to the CDCF Act, 2009 provisions concerning the misuse of funds. Malya and Kessy (2013) argued that, in society where the people are empowered-citizens, incidents of corruptions are reported to the relevant organs of the states. As such, in the community which has the tradition of patriotism; transparency and accountability cannot tolerate fraud or misappropriate use of the funds. A compelling case for the development of CDFs must identify set tools that compel transparent and ethical use of such funds in a manner that is free of corruption (Baskin, 2020). According to Reich, (2018) punishment in such phenomena is salient because it is the demonstration of accountability. 
The fine provided in the study area is lesser than that indicated in the Act. Villagers might have the tradition of being merciful to their fellow villagers even if they are wrong doers. This is unhealthy to the communities, because wrong doers may be encouraged to misbehave, because, sometimes, punishment given may not make them learn their mistakes. Lesser punishment is contrary to the CDCF Act with regard to legal measures in case of the misuse of the fund, village officers require abiding with CDCF Act, 2009; this will bring meaning to implementation of the funds.

\subsection{Conclusion and Policy Recommendations}

The study concludes that; the process of initiation of the projects seem not practical in a real sense, because villagers do not initiate new projects to be funded by $\mathrm{CDCF}$, but selected them from the existing projects that are at implementation stages. This is contrary to Article 12 (1) of the CDCF Act, 2009 and to the Decentralization Theory on the aspect of transfer of authority from central government to the constituency level and ultimately to the ordinary citizens. Ordinary citizens have no total authority in deciding their projects to be funded.

With regard to public procurement process, it was a good practice of selecting local contractors/ suppliers for development projects, though villagers had their own suppliers and contractors even before the introduction of CDCF. Local contractors and suppliers might be patriotic with their village development. Though, it may also encourage the misuse of the funds by knowing that there will be lesser punishment because they know each other in the village.

It is also concluded that, the practice of the CDCF being deposited in the District Council Development Account (DCDA), this may imply that, the district council with two or more constituencies may minimize multiple bank account for the same funds. In this aspect, it is a good practice as long as it does not affect the interest and the essence of the CDCF itself. It is further concluded that, it is good practice and it is in accordance to the CDCF Act, 2009 that, the fund is seriously managed due to the processes it passed until it is used for the development projects. Zero tolerance to any act of funds' misuse is encouraged during the implantation of disbursed funds. Although the punishment to guilt ones is lesser compared with the punishment documented in Article 28 (1-2) of the CDCF Act, 2009.

The study recommended that, CDCF Act, 2009 should be reviewed to meet what is practical in the study area. For instance, Article, 13 (1-2) and 21 (1-4) which are about the initiation of CDCF funded projects. The CDCF Act should state clearly about the projects to be initiated for CDCF disbursement that is it should emphasize on selecting projects from among the existing projects rather than initiating new projects, because this is what is practical in the study area. No new projects are initiated but selected from the projects with are in progressive implementation. It is further recommended that, punishment to citizens who misuse CDCF should be in accordance with article 28 (1) of CDCF Act, 2009 and not as is the case now.

\section{References}

Auya, S. and Oino, P. (2013). The Role of Constituency Development Funds in Rural Development: Experience from North Migirango Constituency, Kenya. International Journal of Science and Research (6):306 - 312.

Baskin, M. and Samrat, L. H. and Ashe, R. (2010). Constituency Development Funds as a Tool of Decentralization Development. In: The workshop: The Role of Parliamentarians in Facilitating Grassroots Projects. State University of New York Centre for International Development. 10-19 September 2010 New York. 33. Pp.

Boesten, J., Mdee, A and Clearer, F. (2011). Service Delivery on the Cheap? Community Based Workers in Development Interventions. Development in Practice 21 (1): 41 - 58.

Chaligha, E. A. (2014) Transparency and Accountability in Local Government in Tanzania. Policy Forum and REPOA. Dar es Salaam. 44 pp.

Chesang, D., Okello, A.C. and Kimitei, J. B. (2016). The Role of Constituency Development Fund in Achieving Equitable Distribution of Resources to Constituencies in Kenya: A Case Study of Baringo Central Constituency. International Journal of Innovative Research \& Development 5 (10): 6-25.

Chesiyna, K.P. and Wanyoike, D. (2016). Determinant of Effective Implementation of CDF Projects in Baringo Central Constituency. Kenya. International Journal of Research in Business Management 4(4): 31- 42.

Chibomba, N.D (2013) CDF as a Tool for Community Development: A case Study of Katuba Constituency in Zambia. Min - Thesis for Award Master of Art Degree at University of Western Cape. South Africa. 109 pp.

Commonwealth Parliamentary Association (CPA), (2016). Handbook on Constituency Development Funds $(C D F s)$. Principles and Tool for Parliamentarians. CPA. London. 64 pp.

Eriksen, S. I. (1994). Introduction Between a Rock and a Hard Place? Development Planning in Tanzania Local Governments. Third world Planning Review 19(3): $251-269$.

Fjeldstad, O. (2001). Fiscal Decentralization in Tanzania: for Better or For Worse? Chr. Michelsen Institute Development Studies and Human Rights. Postterminalen. Norway. 16 pp.

Florence, A (2012) Strategies Applied by CDF Management to Implement Constituency Programme in Mwala Constituency of Kenya. Dissertation for Award of Master Degree, University of Nairobi. 52 pp. 
Francis, K and Nekesa, P and Ndugu B (2009). Best Practices in Constituency Development Fund (CDF) Collaborative Centre for Gender and Development. Nairobi $89 \mathrm{pp}$

Gaventa, J. (2002). Legal and Policy Frameworks of Citizens Participation in Local Government. East African Regional Report. Logolink Research. 43 pp.

Hart, T. and Bryn, W. B. (2016). Fiscal Decentralization. A Public Financial Management Introductory Guide. Overseas Development Instituted. London. $21 \mathrm{pp}$.

Kamau, G. and Muturi. M. (2015) factors Affecting Successful completion of Constituency Development Fund Projects in Kenya: A Case of Nyandarua County. International Journal of Economics, Commerce and Management 3 (5): 499 - 516.

Kausya, J.M., 2007. Political decentralization in Africa: experience of Uganda, Rwanda and South Africa. In: Cheema, G.S and Rondinelli, D.A., eds. 2007. Decentralizing Governance: Emerging Concepts and Practices. Washngton: Brookings Institution Press.75-91 pp

Kisambe, L., Sanga, D. and Kasubi, J. W. (2014) More Than a Decade of Decentralization in Tanzania: Its Implications on Pro-Poor Service Delivery. The Case of Primary Education and Health Services. International Journal of Scientific and Research Publication 4 (12): 1 - 8.

Lawson, A. and Rakner, L. (2005). Understanding Pattern of Accountability in Tanzania. Final Synthesis Report. Oxford Policy Management. Oxford.41 pp.

Machoka, O. P. (2016). Public Procurement Practices and Performance of Selected Constituency Development Funds Projects in Kenya. Dissertation for Award of PhD at Jommo Kenyatta University of Agriculture and Technology, Nairobi, Tanzania. 187 pp.

Malya, T. E. and Kessy, L. F. (2013). Governance, Local Governments and the Constituency Development Catalyst Fund in Tanzania. Journal of Poverty Alleviation and International Development 4 (2): 19 - 54.

Massoi, L. and Norman A. S. (2009). Decentralization by Devolution in Tanzania: Reflection on Community Involvement in the Planning Process in Kizota Ward in Dodoma. Journal of Public Administration and Policy Research 1 (7): 133 - 140.

Mdee, A. and Thorley, L. (2016). Good Governance, Local Government, Accountability and Services Delivery in Tanzania. Exploring the Contest for Creating a Local Governance Performance Index. Economic and Social Research Council. Mzumbe University. Morogoro. 21 pp.

Mello Jr, R.L. (2000). Fiscal Decentralization and Intergovernmental Fiscal Relations: A Cross-Country Analysis. World Development 28 (2): 365 - 380.

Mokou, M. and Omboto, D. (2018). Effective of Public Procurement Practices on Procurement Performance of Constituency Development Fund Projects in Kwale County Government of Kenya. International Journal of Current Research 10 (3): 67333 - 67338.

Mollel, A. H. (2010). Participation for Local Development. The Reality of Decentralization in Tanzania. African Study Center. Leiden.

Muro, E. J. and Namusonge, S.G. (2015). Governance Factors Affecting Community Participation in Public Development Projects in Meru District in Arusha, Tanzania International Journal of science and Technology Research 4 (6): 106 - 110.

Murray, M.C.(2018). Constituency Development Funds: Are they Constitutional? Budget Brief No. 12. International Budget Partnership. Cape Town. 6 pp.

Musonge, M. O. and Mwangangi, P. (2016). The Role of Procurement Management on the Performance of Constituency Development Fund Projects in Kenya. A case study of Kiambu County. Journal of Business and Management 18 (10): 59 - 61.

Mutie, N. and Bomett. J, (2014). The Role of CDF in Provision of Secondary School Education in Kenya. International Journal of Science and Technology Research 3 (8): 429 - 439.

Nkinga, D. S. N. (2003). Public Procurement Reform - The Tanzania Experience: Central Tender Board. Ministry of Finance. Dar es Salaam. 22 pp.

Opiyo, J. Tibbs, Y. C. and Odhiambo, A. (2016) Constituency Development Fund and Projects Implementation in Butere, Kenya. International Journal of Economic, Commerce and Management 4(8): 561 - 570.

Otieno, G. O., Nyadwaki, M. J. Momanyi, G. (2015), Evaluation of the Management and Utilization of Constituency Development Fund on Education Development in Gem Constituency, Siaya District,Kenya. Journal of Research \& Method in Education 5 (2): 27 - 45.

Oyugi L. A. Nyaguthii, E. (2013). Influence of Community Participation on Successful Implementation of CDF Projects in Kenya: Case Study of Mwea Constituency. International Journal of Education and Research. 1(8): 1-16.

Phiri, P. (2016). Community Participation in Constituency Development Fund (CDF) Projects in Lusaka City. The case of Kanyama Constituency. Dissertation for Award of MA at University of Zambia, Lusaka, Zambia. 123 pp.

REPOA (2014) Review of the Governance Effectiveness of the CDCF in Tanzania. REPOA. Dar es Salaam. 44 pp. 
Richerds, A. R. (1962) On Administrative Decentralization. Institute of Public Administration Australia. Sydney. $371 \mathrm{pp}$.

Santiso, C., Nitze, H. P. and Hopkins, J. (2001). Good Governance and Aid Effectiveness: the World Bank and Conditionality. The Georgetown Public Policy Review 7 (1):1- 22.

Shah, A. (2005). (ed). Public Services Delivery. Public Sector Governance and Accountability Series The world Bank. Washington D.C. $219 \mathrm{pp}$

Tshangan, H.A (2010). Constituency Development Funds: Scoping Paper. International Budget Partnership. Cape Town. South Africa. 46 pp.

Tsubura, M. (2014). Accountability and Clientism in Dominant party Politics. The case of Constituency Development Fund in Tanzania. Dissertation for Award of (PhD) Degree at $(\mathrm{PhD})$, University of Sussex. England.210 pp.

United Republic of Tanzania (URT), (2005) The Public Procurement (Selection and Employment of Consultants) Regulations. Government Notice No. 98 of 2005.96 pp.

URT (2009). The Constituencies Development Catalyst Fund Act No. 16 of 2009, President's Office. Dar es Salaam. $17 \mathrm{pp}$.

URT (2012) The National Public Procurement Policy. Ministry of Finance. Dar es Salaam. 37 pp.

URT, (2011). Tanzania Open Government Partnership (OGP) Action Plan. Draft for Consultation. Dar es Salaam. $9 \mathrm{pp}$.

Wild, L., Booth, D., Cunning, C., Forest, M. and Wales, J. (2015). Adopting Development: Improving Services for the Poor. Overseas Development Institute: London. 55 pp.

Yushkov, A. (2015). Fiscal Decentralization and Regional Economic Growth: Theory, Empirics and the Russian Experience. Russian Journal of Economics 1 (4): 404 - 418. 